\title{
Dwór rodziny Rostworowskich w Kęble miejscem edukacji i wychowania dzieci i młodzieży
}

\begin{abstract}
The Rostworowski family manor in Kębło as a place of the education and upbringing of children and adolescents

This article presents the family manor of the Rostworowski family in Kębło and its importance to the education and upbringing of children and adolescents. After 1949, social and educational activities took place in Kębło manor. In the article, I present various forms of caring for children and adolescents, organized in the manor house. It hosted an orphanage, a State-owned Educational Institute for Handicapped Children, which today is a Boarding Special Education School and a Vocational Preparation School.

The State-owned Orphanage operated in Kębło between 1947 and 1982. Now it houses a Special Education Centre and a three-year Work Vocational Preparation School where pupils absorb the knowledge and acquire the skills to help them lead independent lives. As part of practical classes, students grow and care for vegetables and herbs, tend rock gardens and plants, bake cakes, make preserves and prepare simple dishes.
\end{abstract}

Keywords: education, upbringing, children, young people, manor house

Kębło to mała wioska położona w północno-zachodniej części województwa lubelskiego, w powiecie puławskim w dolinie rzeki Bystrej, w odległości około $1 \mathrm{~km}$ od Wąwolnicy - miejscowości, w której znajduje się znane większej rzeszy ludzi Sanktuarium Matki Bożej Kębelskiej.

Historia Kębła wiąże się nierozerwalnie z objawieniem się figury Matki Bożej, zwanej Kębelską ${ }^{1}$. Tradycja kultu Matki Bożej sięga końca XIII w., w którym miały miejsce najazdy Tatarów. W 1278 r. Tatarzy po zniszczeniu Lublina udali się do grodu Ottona Jastrzębczyka w Wąwolnicy. Wódz tatarski, dowiedziawszy się, że właściciel grodu

${ }^{1}$ Historia, zabytki, turystyka, informator, mapa gminy. Wąwolnica. Przewodnik, opracowanie: Biuro Public Relations, s. 5. 
przebywa w Głusku Opolskim, udał się do tej miejscowości zostawiwszy tabory ze zrabowanymi łupami w Kęble. W tym czasie Tatarzy w taborze odnaleźli figurkę Matki Bożej, ustawili ją na kamieniu i zaczęli ją ośmieszać i bezcześcić ${ }^{2}$. Wówczas, jak opisują księgi parafialne: nad Matką Boża ukazała się jasność i unosić zaczęła się w górę, na przeciwległej górze o paręset kroków stanęła na lipie, jakoby uchodzac z rąk niewiernych. Po ich ucieczce statua Matki Bożej nazad stanęła na kamieniu. Od tego wydarzenia miejsce to było licznie odwiedzane przez ludzi wierzących. Dziedzic Wąwolnicy - Otton Jastrzębczyk zdecydował, aby w tym miejscu wybudować drewniany kościół, w którym umieszczona została figurka Matki Bożej³ 8 września 1700 r. figurę przeniesiono do kościoła parafialnego w Wąwolnicy, gdzie po dziś dzień ukazana jest w głównym ołtarzu. W miejscu cudownego objawienia postawiona została kapliczka4.

Miejscowość Kębło było wsią królewską. Zmieniało swoich właścicieli od XVI w. Kolejno przechodziło przez ręce Firlejów, Tarłów, Lubomirskich, później było własnością Teofili z Sanguszków Potockiej. W latach 1829-1832 Kębło należało do rodziny Czartoryskich $^{5}$. Następnie właścicielem majątku została rodzina Wesslów. W 1880 r. Wesslowie na wzgórzu, w pobliżu miejsca objawienia, wybudowali dworek otoczony parkiem. Przy wejściu do dworku na płycie widnieje napis „Salve 1880”. Ignacy Wessel dostał Kębło jako nagrodę za niszczenie ruchu narodowowyzwoleńczego. Jego despotyczna postawa była przyczyną wybuchu buntu miejscowych ludzi ${ }^{6}$.

Żona Wessla, Zofia z Rostworowskich, uratowała od rozbiórki kapliczkę Matki Boskiej Kębelskiej. Prężnie działała w Lubelskim Towarzystwie Dobroczynności. W 1910 r. Antoni Rostworowski kupił Kębło od Ignącego Wessla. Bardzo szybko odegrał znaczącą rolę na ziemi nałęczowskiej. Od roku 1905 był współzałożycielem Lubelskiego Towarzystwa Rolniczego. Swoją działalność zaczął od zakładania szkół. W Kęble ufundował 4-klasową, prywatną szkołę dla dzieci folwarcznych. W sąsiednim Rogalowie ofiarował budynek na spółdzielnię, w którym wyodrębnił izbę dla tamtejszej szkoły. Był członkiem Dozoru Szkolnego Gminy Drzewce. Antoni Rostworowski od momentu przybycia do Kębła był członkiem dozoru kościelnego w Wąwolnicy. Dziedzic Kębła swoimi funduszami przyczynił się do budowy kościoła parafialnego pod wezwaniem św. Wojciecha ${ }^{7}$. W Nałęczowie wspierał budowę Szkoły Gospodarskiej Męskiej, przeznaczonej dla chłopców od 17. do 20. roku życia. W roku szkolnym 1907/1908 władze rosyjskie wyraziły jedynie zgodę na prowadzenie rolniczych kursów zimowych w języku polskim dla rolników. Z czasem kursy te przekształciły się w szkolę. A. Rostworowski często wygłaszał tam pogadanki oraz wykłady. Przy jego współudziale w 1908 r. powstała Szkoła Ziemianek w Nałęczowie, której kierowniczką została Aleksandra Serwatowska. Od

${ }^{2}$ H. Kuś, Wąwolnica i okolice, Wydawnictwo Językowe Apart, 2005, s. 28.

3 I. Stelmach, Małe ojczyzny - Kębło, ,Widnokrąg” 2 (2006), s. 15.

${ }^{4}$ I. Stelmach, op. cit., s. 15.

5 H. Kuś, op. cit., s. 12.

${ }^{6}$ I. Stelmach, op. cit., s. 16.

7 http://www.sanktuarium-wawolnica.pl/czytelnia/Rostworowski\%20dziedzic\%20Kebla\%20pdf.pdf [11.04.2015]. 
1908 r. dziedzic Kębła brał czynny udział w Polskim Towarzystwie Krajoznawczym ${ }^{8}$. A. Rostworowski był skarbnikiem Towarzystwa Przyjaciół Uniwersytetu Lubelskiego, założonego przez ks. Idziego Radziszewskiego. Dzięki jego pomocy poszczególne sale uniwersyteckie fundowały rodziny ziemiańskie; wymienić tu należy Wesslów i Rostworowskich ${ }^{9}$. W latach 1912-1913 A. Rostworowski organizował w Kęble tajne obozy harcerskie $^{10}$. W latach dwudziestolecia międzywojennego Kębło należało już do rodziny Janiszewskich ${ }^{11}$.

W roku 1943 dwór stał się przez dziewięć miesięcy schronieniem dla dzieci ewakuowanych przez Niemców z sierocińca w Lublinie ${ }^{12}$. W 1944 r. majątek został rozparcelowany $^{13}$.

W 1945 r. majątek Kębło zyskał nowego właściciela. Było nim Kuratorium Okręgu Szkolnego Lubelskiego w Lublinie. Kuratorium postawiło sobie za cel założenie w dworku domu wypoczynkowego dla pracowników administracji szkolnej. Zgodnie z decyzją Kuratora Okręgu Szkolnego Franciszka Krzemienia-Ojaka w dworku utworzono jednak Państwowy Dom Dziecka. Tekst postanowienia dotyczącego utworzenia placówki w pałacu był następujący: Przekazuję z dniem 1 stycznia 1947 roku ośrodek majątku Kębło w powiecie puławskim na cele opieki społecznej i polecam zorganizować tam stały Dom Dziecka dla sierot będacych pod opieka Wydziału Opieki nad Dzieckiem przy Kuratorium Okręu Szkolnego w Lublinie. Grunty i budynki należace do Ośrodka moga być użytkowane od tego terminu wytącznie na cele opieki nad dziećmi ${ }^{14}$.

Państwowy Dom Dziecka w Kęble od 1 września 1946 r. miał swoją siedzibę w Puławach przy ul. Dąbrowskiego 12, a następnie 30 sierpnia 1947 r. został przeniesiony do Kębła. Z zakładu puławskiego przeniesiono jedenaścioro dzieci (2 chłopców i 9 dziewczynek). Personel nowo powstałego Domu Dziecka przeniesiono z Puław. W jego skład wchodziły następujące osoby: kierowniczka, dwie wychowawczynie oraz kucharka. $\mathrm{Na}$ potrzeby zakładu przeznaczono początkowo sześć pomieszczeń mieszkalnych, tj.: sypialnię dla dzieci, sypialnię dla personelu, jadalnię, świetlicę, pokój dla kierowniczki, magazyn, kuchnię, łazienkę-umywalnię, hol i szatnię ${ }^{15}$.

Już po miesiącu działalności Domu Dziecka liczba wychowanków wzrosła do 16 podopiecznych (10 dziewczynek i 6 chłopców). Wychowankowie otrzymywali w ośrodku

\footnotetext{
8 Ibidem.

9 S. Rostworowski, Rostworowscy w Kęble, „Gazeta Wąwolnicka” 7 (2004), s. 2.

${ }^{10} \mathrm{http} / /$ www.sanktuarium-wawolnica.pl/czytelnia/Rostworowski\%20dziedzic\%20Kebla\%20pdf.pdf [11.04.2015].

11 H. Kuś, op. cit., s. 30

12 E. Czerwińska, Dzieci świętego Franciszka, „Kurier Lubelski” 267 (2002), s. 4.

13 I. Stelmach, op. cit., s. 16.

${ }^{14}$ Archiwum Państwowe w Lublinie, zespół: Kuratorium Okręgu Szkolnego Lubelskiego w Lublinie, sygnatura: 35/702/0/996, jednostka: Akta dotyczące Państwowego Domu Dziecka w Kęble pow. Puławy.

15 Ibidem, zespół: Kuratorium Okręgu Szkolnego Lubelskiego w Lublinie, sygnatura: 35/702/0/996, jednostka: Akta dotyczące Państwowego Domu Dziecka w Kęble pow. Puławy.
} 
wyżywienie i odzież ${ }^{16}$. W październiku 1948 r. liczba podopiecznych znacznie wzrosła i wynosiła 51 dzieci $^{17}$.

Państwowy Dom Dziecka mieścił się w byłych budynkach pofolwarcznych; w swoim posiadaniu miał: dom mieszkalny - pałac w parku, w którym znajdował się zakład, zabudowania gospodarcze, ogródek warzywny, sad i nieużytki. Ogólny obszar całej posiadłości wynosił 33 ha $9460 \mathrm{~m}^{2}$. Gospodarstwem należącym do Państwowego Domu Dziecka zarządzał kierownik zakładu. W zakładzie prowadzono hodowlę żywego inwentarza oraz świń ${ }^{18}$.

$\mathrm{Na}$ podstawie protokołu z kontroli Państwowego Domu Dziecka w Kęble w roku 1951, można się dowiedzieć, jak wyglądał pałac i jakie było jego wyposażenie. W suterenach budynku były natryski, dwa magazyny żywnościowe, dwie piwnice na węgiel i ziemniaki, pralnia oraz ubikacja. Na parterze znajdował się: pokój kierownika, jadalnia, kuchnia, dwie świetlice, bawialnia dla młodszych dzieci, jedna duża sypialnia dla dziewcząt, weranda, łazienka i ubikacje dla dziewcząt oraz hol (szatnia). Na pierwszym piętrze usytułowane były: cztery sypialnie dla chłopców, izolatka, dwa małe pokoje dla higienistki i intendentki, magazyn odzieżowy. Na poddaszu znajdował się jeden pokój przeznaczony dla krawcowej na pracownię krawiecką i na mieszkanie ${ }^{19}$.

W majątku Kębło, oprócz pałacu, znajdowała się też tzw. rządcówka. Był to murowany budynek, w którym mieszkali wychowawcy oraz personel gospodarczy. Niedaleko dworku usytuowana była tzw. oficyna. Budynek ten zajmowali pracownicy Państwowego Domu Dziecka, a także byli pracownicy folwarczni, którzy otrzymali działki w wyniku reformy rolnej ${ }^{20}$.

Według protokołu z kontroli przeprowadzonej w 1951 r. w zakładzie było 80 podopiecznych, z czego chłopców było 47, dziewcząt w wieku od 5. do 17. roku życia - 33; dzieci całkowicie osieroconych było 37, zaś półsierot 43. Analizując pochodzenie dzieci przebywających w Domu Dziecka, można zauważyć, że najwięcej podopiecznych pochodziło z rodzin chłopskich (42 dzieci), znaczna liczba wychowanków wywodziła się $\mathrm{z}$ rodzin robotniczych (32 dzieci). W placówce były także dzieci inteligencji pracującej (5 wychowanków). Zdarzało się, że pochodzenie dziecka było nieznane (w 1951 r. był jeden taki wychowanek) $)^{21}$.

Starsze dzieci z Domu Dziecka należały do Wiejskiego Koła Związku Młodzieży Polskiej w Kęble, natomiast młodsze przynależały do Związku Harcerstwa Polskiego, który prowadziła Szkoła Podstawowa w Wąwolnicy. Starsi podopieczni należeli także do

${ }^{16}$ Ibidem, zespół: Akta gminy w Wąwolnicy, sygnatura: 35/598/0/-/57, jednostka: Sprawozdanie z działalności Gminnego Referatu Opieki Społecznej za miesiąc październik 1948 r.

17 Ibidem, zespół: Akta gminy w Wąwolnicy, sygnatura: 35/598/0/-/54, jednostka: Akta opieki.

${ }^{18}$ Ibidem, zespół: Akta gminy w Wąwolnicy, sygnatura: 35/598/0/-/20, jednostka: Komisja Oświatowo-Kulturalna gm. Wąwolnica 1949-1954.

19 Ibidem, zespół: Akta gminy w Wąwolnicy, sygnatura: 35/598/0/-/20, jednostka: Komisja Oświatowo-Kulturalna gm. Wąwolnica 1949-1954.

${ }^{20}$ Ibidem.

${ }^{21}$ Ibidem. 
Towarzystwa Przyjaźni Polsko-Radzieckiej i Polskiego Czerwonego Krzyża. Pracownicy zakładu przynależeli do Związku Nauczycielstwa Polskiego oraz Zespołu Opieki Zdrowotnej (ZOZ) w Kęble. W Państwowym Domu Dziecka działał samorząd dziecięcy, do którego należeli wszyscy wychowankowie. Samorząd składał się z siedmiu sekcji: sekcji sanitarno-porządkowej, sekcji samopomocy koleżeńskiej, sekcji kulturalno-oświatowej, sekcji artystycznej, sekcji robót ręcznych i majsterkowania, sekcji sportowej oraz sekcji dyscypliny socjalistycznej22. W ramach tego podziału podopieczni pełnili dyżury w sypialniach, świetlicach i jadalni. Starsi wychowankowie pomagali przy pracach w kuchni ${ }^{23}$.

Dzieci do Państwowego Domu Dziecka przyjmowano na podstawie skierowania wystawianego przez Kuratorium Okręgu Szkolnego w Lublinie lub Inspektoratu Szkolnego w Puławach. Opiekę nad placówką sprawowała formalnie Szkoła Weterynaryjna Wojskowa w Puławach ${ }^{24}$. Państwowy Dom Dziecka w Kęble zwolniony był od opłacania podatków, ponieważ służył on na cele dobroczynne ${ }^{25}$.

Wychowawcy kładli duży nacisk na odrabianie lekcji oraz utrwalanie wiadomości zdobytych w szkole ${ }^{26}$. W wolnym czasie dzieci mogły rozwijać swoje zdolności w kołach zainteresowań. Największą popularnością cieszyło się kółko modelarskie. Podopieczni zakładu wykonywali na tych zajęciach modele samolotów i szybowców. Robili również rzeczy przydatne do codziennego użytku, np. szufelki, wieszaki. Dla dziewcząt najciekawszymi zajęciami były: wykonywanie lalek, które były wykorzystywane w teatrzyku kukiełkowym, wyszywanie oraz haftowanie serwetek. Dla najmłodszych dzieci organizowane były wieczory bajek. Poza wymienionymi zajęciami przygotowywano także wieczorki taneczne, konkursy typu zgaduj-zgadula oraz zawody sportowe. Organizowano też spotkania ze znanymi ludźmi. Wychowankowie uczyli się pracy w gospodarstwie pomocniczym. W Domu Dziecka w Kęble podopieczni podzieleni byli na grupy wychowawcze. Każda grupa posiadała swój zestaw narzędzi do prac gospodarczych. Do dyspozycji każdej z grup był również sprzęt mechaniczny, który miał służyć do realizacji programu wychowania estetycznego, rozwijania samodzielności i gospodarności ${ }^{27}$. Wychowankowie w domu dziecka pracowali przy siewie, żniwach, wykopkach, hodowli trzody chlewnej i bydła. Uczęszczali do szkoły podstawowej w Wąwolnicy, a także do innych średnich szkół zawodowych (np. do Szkoły Spółdzielczej w Nałęczowie) i mieszkali w przyszkolnych internatach ${ }^{28}$.

\footnotetext{
${ }^{22}$ Ibidem.

${ }^{23}$ Ibidem, zespół: Kuratorium Okręgu Szkolnego Lubelskiego w Lublinie, sygnatura: 35/702/0/996, jednostka: Akta dotyczące Państwowego Domu Dziecka w Kęble pow. Puławy.

${ }^{24}$ Ibidem, zespół: Akta gminy w Wąwolnicy, sygnatura: 35/598/0/-/20, jednostka: Komisja Oświatowo-Kulturalna gm. Wąwolnica 1949-1954.

${ }^{25}$ Ibidem, zespół: Akta gminy w Wąwolnicy, sygnatura: 35/598/0/-/25, jednostka: Komisja Kontroli Społecznej gm. Wąwolnica.

${ }^{26}$ Ibidem, zespół: Kuratorium Okręgu Szkolnego Lubelskiego w Lublinie, sygnatura: 35/702/0/996, jednostka: Akta dotyczące Państwowego Domu Dziecka w Kęble pow. Puławy.

${ }^{27}$ Archiwum Muzeum Oświatowego w Puławach, sygnatura: Mo/A/285/94, Państwowe Domy Dziecka.

${ }_{28}$ Archiwum Specjalnego Ośrodka Szkolno-Wychowawczego w Kęble (dalej: ASO), Kronika Państwowego Domu Dziecka w Kęble.
} 
Dom Dziecka w Kęble posiadał bibliotekę. W 1950 r. w zbiorach biblioteki znajdowało się 171 tomów różnej treści. W czytelni wychowankowie mieli dostęp do następujących czasopism: „Sztandar Ludu”, „Trybuna Wolności”, „Chłopska Droga”, „Żołnierz”, „Gromada”. Podopieczni mogli korzystać także z kilku czasopism dziecięcych ${ }^{29}$.

W dniu 12 października 1965 r. powstała w Kęble drużyna harcerska. Założył ją druh Józef Kojtych - wychowawca w Państwowym Domu Dziecka. Pierwszym wspólnym zadaniem nowopowstałej drużyny było zrobienie boiska do gry w siatkę dla wychowanków placówki. Harcerzami mogli zostać tylko ci podopieczni, którzy osiągali najlepsze wyniki w nauce. Drużyna przygotowywała dla swoich kolegów gry i zabawy sportowe, organizowała wycieczki krajoznawcze. Zajmowała się również zalesianiem pobliskich terenów ${ }^{30}$.

Harcerze z Kębła zapraszali do Domu Dziecka harcerzy z Wąwolnicy na rozgrywki sportowe. Podczas ich trwania młodzi ludzie mogli nawiązywać przyjaźnie i integrować się ze sobą. Nad sprawnym zorganizowaniem tego typu spotkań czuwali wychowankowie, zwłaszcza ci, którzy należeli do sekcji gospodarczej oraz higieniczno-porządkowej $^{31}$.

Dzieci w zakładzie otrzymywały cztery posiłki w ciągu dnia: pierwsze śniadanie, drugie śniadanie, obiad i kolację. W święta oraz w niedzielę wychowankowie dostawali dodatkowo desery ${ }^{32}$.

O zdrowie wychowanków dbał lekarz z Wąwolnicy. Wychowankom poświęcał pięć godzin miesięcznie. Naprawą oraz szyciem ubrań dla podopiecznych zajmowała się krawcowa zakładowa ${ }^{33}$.

Kadra kierownicza Państwowego Domu Dziecka często się zmieniała. Skąpa jest też wiedza o dyrektorach tejże placówki. Pierwszym kierownikiem była Jadwiga Binięda. Funkcję tę pełniła do 1 lutego 1948 r. Następnym kierownikiem od 1 lutego 1948 do kwietnia 1949 r. był Henryk Jaroszyński ${ }^{34}$. Od 1 kwietnia 1949 r. do 1 marca 1952 r. funkcję kierowniczą pełnił Stanisław Sobolewski. Od 1 marca 1952 do 31 stycznia 1954 r. S. Sobolewski pracował na stanowisku starszego księgowego w tej placówce. Zajmował się prowadzeniem kancelarii i rachunkowości Domu Dziecka. S. Sobolewski posiadał średnie wykształcenie (tzw. dużą maturę). Ukończył ośmioklasowe Gimnazjum w Przemyślu. Po nim do 31 sierpnia 1955 r. Dom Dziecka w Kęble był pod zarządza-

${ }^{29}$ APL, zespół: Kuratorium Okręgu Szkolnego Lubelskiego w Lublinie, sygnatura: 35/702/0/996, jednostka: Akta dotyczące Państwowego Domu Dziecka w Kęble pow. Puławy.

${ }^{30}$ Ibidem.

${ }^{31}$ Ibidem.

32 APL, zespół: Akta gminy w Wąwolnicy, sygnatura: 35/598/0/-/20, jednostka: Komisja Oświatowo-Kulturalna gm. Wąwolnica 1949-1954.

${ }^{33}$ Ibidem.

${ }^{34}$ Ibidem, zespół: Kuratorium Okręgu Szkolnego Lubelskiego w Lublinie, sygnatura: 35/702/0/996, jednostka: Akta dotyczące Państwowego Domu Dziecka w Kęble pow. Puławy. 
niem Stanisława Koreckiego. S. Korecki wcześniej był kierownikiem Szkoły Podstawowej w Braciejowicach w woj. lubelskim (1945-1952) ${ }^{35}$.

Mikołaj Tomczuk zarządzał zakładem 15 lat. Funkcję tę sprawował od 1 września 1955 do 31 grudnia 1970 r., czyli do czasu przejścia na emeryturę ${ }^{36}$. M. Tomczuk razem z żoną Leokadią Tomczuk, która od 1955 r. rozpoczęła pracę w Kęble jako wychowawca kontraktowy, z wielką troską i zrozumieniem traktowali wychowanków. Byli dumni z ich osiągnięć w szkole. Swojej pracy poświęcili się z pasją i zaangażowaniem. L. Tomczuk troszczyła się, aby podopieczni zdobywali jak najwięcej wiedzy i doświadczeń. Prowadziła różnorodne koła zainteresowań. W Domu Dziecka zorganizowała grupę teatralną, dla której szyła stroje i tworzyła dekoracje. Powołała również zespół muzyczny i chór ${ }^{37}$. M. Tomczuk wpajał swoim podopiecznym zasadę, że ważniejsze jest „być” niż „mieć”. Za wzorową pracę wychowawczą i społeczną został odznaczony Złotym Krzyżem Zasługi, Krzyżem Kawalerskim Orderu Odrodzenia Polski, a także wieloma dyplomami ${ }^{38}$.

Ostatnim kierownikiem Państwowego Domu Dziecka był Jan Lipnicki. Stanowisko to objął 1 lutego 1971 r. J. Lipnicki, zanim objął posadę dyrektora, był wychowawcą w tejże placówce (1955-1971). W zawodzie pedagoga pracował od 1 lipca 1951 r. Do 1953 r. był wychowawcą w Państwowym Domu Dziecka w Turkowicach. W latach 1975-1980 studiował pedagogikę opiekuńczą na Uniwersytecie Marii Curie-Skłodowskiej w Lublinie i uzyskał tytuł magistra. 23 czerwca 1976 r. J. Lipnicki został odznaczony Złotym Krzyżem Zasługi za dwudziestoletnią nienaganną pracę pedagogiczną a także dwukrotnie dostał nagrodę Kuratora. Od 1 września 1982 r. podjął się kierowania Państwowym Zakładem Wychowawczym dla dzieci upośledzonych, który powołano w miejsce Domu Dziecka. Funkcję tę pełnił do 31 sierpnia 1987 r. Wtedy to uzyskał uprawnienia emerytalne. W 1983 r. ukończył studia podyplomowe na kierunku organizacja i zarządzanie oświatą w Centrum Doskonalenia Nauczycieli IKN w Sulejówku³ ${ }^{39}$.

Dnia 1 września 1982 r. majątek Państwowego Domu Dziecka przekazano do użytkowania Państwowemu Zakładowi Wychowawczemu dla dzieci upośledzonych. Od 17 kwietnia 1984 r. Kuratorium Oświaty i Wychowania w Lublinie zmienia nazwę na Specjalny Ośrodek Szkolno-Wychowawczy w Kęble ${ }^{40}$.

Specjalny Ośrodek Szkolno-Wychowawczy w Kęble jest placówką przeznaczoną dla młodzieży od 16. do 24. roku życia, upośledzonej w stopniu umiarkowanym i znacznym, 2436 .

35 Archiwum Kuratorium Oświaty w Lublinie, Teka akt osobowych: Sobolewski Stanisław, sygnatura:

36 Ibidem, Teka akt osobowych: Tomczuk Mikołaj, sygnatura: 69.

37 S. Jędrych, Ludwika Leokadia Tomczuk, w: Biografie nauczycieli zasłużonych dla oświaty i środowiska regionu puławskiego, tom trzeci, red. S. Pać i in., Wydawca: Towarzystwo Muzeum Oświatowego w Puławach, Puławy 2007, s. 80.

${ }^{38}$ S. Jędrych, Mikołaj Tomczuk w: Biografie nauczycieli zastużonych dla oświaty $i$ środowiska regionu puławskiego, tom trzeci, red. S. Pać i in., Wydawca: Towarzystwo Muzeum Oświatowego w Puławach, Puławy 2007, s. 83 .

39 Archiwum Kuratorium Oświaty w Lublinie, Jan Lipnicki, sygnatura: 8314.

${ }^{40}$ http://zsosw.net.pulawy.pl/keblo/o_osrodku.html [9.04.2015]. 
a także z różnymi sprzężeniami: autyzmem, zaburzeniami aparatu ruchu i mowy ${ }^{41}$. W skład Ośrodka wchodzą: trzyletnia Szkoła Przysposabiająca do Pracy oraz Internat ${ }^{42}$.

Na podstawie decyzji Kuratora Oświaty i Wychowania w Lublinie, 1 stycznia 1985 r. Specjalny Ośrodek Szkolno-Wychowawczy w Kęble przekształcono w samodzielną jednostkę budżetową, podporządkowaną Kuratorium. Od 1 września 1996 r. w Ośrodku rozpoczęła działalność Szkoła Przysposabiająca do Pracy Zawodowej dla Upośledzonych w Stopniu Umiarkowanym i Znacznym. Szkoła została stworzona z klas przysposabiających do pracy zawodowej ${ }^{43}$.

Na wniosek Rady Pedagogicznej, Kurator Oświaty w Lublinie 1 czerwca 1997 r. nadał Specjalnemu Ośrodkowi Szkolno-Wychowawczemu w Kęble imię Świętego Franciszka z Asyżu. Wybór św. Franciszka na patrona nie był przypadkowy, ponieważ ten „Biedaczyna z Asyżu” mówi nam w swój cichy i radosny sposób, że trzeba się cieszyć tym, co się ma, każdym dniem, każdą pogodą, każdym darem, jaki się w życiu otrzymuje. Św. Franciszek był bratem całego stworzenia. Rozdał wszystko, co posiadał, wybrał najmniejszych i najsłabszych. Nikim nie gardził, prowadził ludzi do Boga przez wyrozumiałość dla ludzkiej słabości, serdeczność i prostotę. Franciszek jest uosobieniem radości życia, miłości i akceptacji istnienia ${ }^{44}$.

W dniu 1 września 2003 r., zgodnie z uchwałą Rady Powiatu Puławskiego z dnia 21 maja 2003 r. połączono Specjalny Ośrodek Szkolno-Wychowawczy im. Marii Grzegorzewskiej z siedzibą w Puławach i Specjalny Ośrodek Szkolno-Wychowawczy im. św. Franciszka z Asyżu z siedzibą w Kęble w Zespół Specjalnych Ośrodków Szkolno -Wychowawczych w Puławach. 1 września 2006 r., uchwałą Rady Powiatu w Puławach w Ośrodku w Kęble założono trzyletnią Szkołę Specjalną Przysposabiającą do Pracy ${ }^{45}$.

Ośrodek w Kęble przygotowuje podopiecznych do samodzielnego funkcjonowania w społeczeństwie na miarę ich możliwości. To założenie realizowane jest przez: zajęcia dydaktyczne i wychowawcze prowadzone w szkole i w internacie, zajęcia teoretycznej i praktycznej nauki zawodu oraz zajęcia rewalidacyjne ${ }^{46}$. W Ośrodku prowadzone są in-

${ }^{41}$ Edukacja w powiecie puławskim 2011/2012, Powiat puławski, Puławy 2011, s. 44.

${ }^{42}$ Broszura: Oferta edukacyjna Specjalnego Ośrodka Szkolno-Wychowawczego im. świętego Franciszka z Asyżu w Kęble.

${ }^{43}$ ASO, Akt założycielski Szkoły przysposabiającej do pracy zawodowej dla upośledzonych umysłowo w stopniu umiarkowanym i znacznym w Kęble.

44 Ibidem, Akt nadania imienia; Święty Franciszek urodził się w 1182 r. w Asyżu. Fantazja popchnęła młodego Bernardone ku rycerskim ideałom i poezji. Udział w lokalnych konfliktach zakończył się dla niego ponad roczną niewolą, która odbiła się na jego zdrowiu. Pod wpływem choroby Franciszek zmienił swoją postawę do życia i do religii. Udał się na pielgrzymkę do Rzymu. Żebracy, chorzy, kalecy poruszyli jego serce i duszę. Postanowił przebrać się w żebraczy strój i prosić o jałmużnę. Wkrótce powrócił do rodzinnego miasta. Oddawał się medytacji i modlitwie. Decydującym momentem w procesie nawrócenia Świętego Franciszka było spotkanie z ludźmi cierpiącymi na trąd. Franciszek zmarł 3 października 1226 r. (A. Zając, Święty Franciszek, Wydawnictwo Apostolstwa Modlitwy, Kraków 2006, s. 9-26).

45 http://zsosw.net.pulawy.pl/keblo/o_osrodku.html [9.01.2012].

46 Broszura: Oferta edukacyjna Specjalnego Ośrodka Szkolno-Wychowawczego im. świętego Franciszka z Asyżu w Kęble. 
dywidualne programy uwzględniające specjalne potrzeby podopiecznych, przy zastosowaniu aktywizujących metod nauczania. Kadra pedagogiczna dba, aby młodzi ludzie mogli rozwijać swoje zainteresowania, odkrywać swój potencjał i zadowolenie z własnych działań ${ }^{47}$.

Uczniowie w szkole przysposabiającej do pracy nabywają wiedzę i poszerzają umiejętności, które umożliwią im samodzielne funkcjonowanie w życiu codziennym. W ramach zajęć praktycznych wychowankowie uprawiają i pielęgnują warzywa i zioła na działce, dbają o skalniaki, krzewy, pieką ciasta, robią przetwory oraz przygotowują proste potrawy ${ }^{48}$.

$\mathrm{Na}$ terenie Ośrodka funkcjonuje stadnina koni. Wychowankowie biorą udział w zajęciach hipoterapii, które dają im możliwość lepszego funkcjonowania w sferze fizycznej, emocjonalnej, społecznej oraz poznawczej ${ }^{49}$.

Ośrodek w Kęble jest instytucją państwową mającą świecki charakter, kształcącą i wychowującą zgodnie z tradycjami narodu polskiego i powszechnie obowiązującymi normami moralnymi ${ }^{50}$. Ośrodek jest placówką ponadregionalną - uczy się tu i mieszka młodzież pochodząca $\mathrm{z}$ różnych powiatów i województw ${ }^{51}$.

Dwór, który stanowi obecnie siedzibę Ośrodka Szkolno-Wychowawczego od wschodu i zachodu otaczają malownicze wąwozy. Wybudowany został w latach 1873-1880. Jest murowany, część centralna posiada tylko parter, zaś skrzydła boczne są dwupiętrowe. Wewnątrz budynku do dzisiaj zachowały się podłogi i posadzki, a także kaflowe piece ozdobione gzymsami. Niedaleko pałacu znajdują się następujące budynki, które ocalały: folwark, spichlerz i rządcówka. Budynki te pochodzą z przełomu XIX i XX w. W XIX w. funkcjonował tam zespół gorzelni ufundowanych przez ród Czartoryskich. Rozebrano go w latach 70. XX w. ${ }^{52}$

Pałac jest zbudowany z cegły, otynkowany, piętrowy, podpiwniczony, nakryty dachem krytym blachą, na planie prostokąta, z dwoma ryzalitami - jednym prostokątnym, drugim półkolistym. Układ wnętrza jest dwutraktowy, strop betonowy, podłogi zrobione są z desek. Powierzchnia budynku wynosi $850 \mathrm{~m}^{2}$. Wokół budynku roztacza się rozległy, dziesięciohektarowy park $^{53}$.

Dwór w Kęble 12 marca 1990 r. został wpisany do rejestru zabytków, który prowadzi Lubelski Wojewódzki Konserwator Zabytków w Lublinie. Jakiekolwiek prace remonto-

47 Edukacja w Powiecie puławskim..., s. 44-45.

48 Ibidem, s. 45.

${ }^{49}$ M. Pluta, Rekreacja - jeden z celów hipoterapii?, w: Koń w turystyce i rekreacji, red. K. Chmiel, Państwowa Szkoła Wyższa im. Papieża Jana Pawła II w Białej Podlaskiej, Instytut Turystyki i Rekreacji, Biała Podlaska 2009, s. 63.

${ }^{50}$ ASO, Statut Specjalnego Ośrodka Szkolno-Wychowawczego w Kęble im. Św. Franciszka z Asyżu, s. 3.

${ }^{51} \mathrm{http}: / /$ www.szkolnictwo.pl/szko\%C5\%82a,zawodowa,K\%C4\%99b\%C5\%82o,PB6699,Specjalny+ OC5\%9Brodek+Szkolno-Wychowawczy [9.01.2012].

52 Waqwolnica, seria: Pod herbami, Wydawnictwo MAKI, Lublin, s.12.

${ }^{53}$ http://panel.lfoz.lublin.pl/index/show/id/1097/nazwa/keblo-dwor\#Files (05.02.2012). 
we czy budowlane przy pałacu muszą być zgodne z wytycznymi i zaleceniami Lubelskiego Wojewódzkiego Konserwatora Zabytków ${ }^{54}$.

Obecnie w niewielu pałacach kwitnie działalność opiekuńczo-wychowawcza. Dwór w Kęble jest przykładem tego, jak w doskonały sposób można wykorzystać zabytek, z którego korzysta młode pokolenie Polaków. W placówce tej od 1947 r. do chwili obecnej prowadzona jest opieka nad dziećmi i młodzieżą. W różnorodnych formach opieki wychowywała się i kształciła tu dość duża liczba potrzebującej młodzieży. Dwór rodziny Rostworowskich w Kęble pełnił i pełni doniosłe znaczenie w edukacji i wychowaniu dzieci i młodzieży.

\section{Bibliografia}

Źródła archiwalne

Archiwum Kuratorium Oświaty w Lublinie:

Jan Lipnicki, sygnatura: 8314.

Teka akt osobowych: Sobolewski Stanisław, sygnatura: 2436.

Teka akt osobowych: Tomczuk Mikołaj, sygnatura: 69.

Archiwum Muzeum Oświatowego w Puławach:

sygnatura: Mo/A/285/94, Państwowe Domy Dziecka.

Archiwum Państwowe w Lublinie:

zespół: Akta gminy w Wąwolnicy, sygnatura: 35/598/0/-/20, jednostka: Komisja Oświatowo-Kulturalna gm. Wąwolnica 1949-1954.

zespół: Akta gminy w Wąwolnicy, sygnatura: 35/598/0/-/25, jednostka: Komisja Kontroli Społecznej gm. Wąwolnica.

zespół: Akta gminy w Wąwolnicy, sygnatura: 35/598/0/-/54, jednostka: Akta opieki.

zespół: Akta gminy w Wąwolnicy, sygnatura: 35/598/0/-/57, jednostka: Sprawozdanie z działalności Gminnego Referatu Opieki Społecznej za miesiąc październik 1948 r.

zespół: Kuratorium Okręgu Szkolnego Lubelskiego w Lublinie, sygnatura: 35/702/0/996, jednostka: Akta dotyczące Państwowego Domu Dziecka w Kęble pow. Puławy.

Archiwum Specjalnego Ośrodka Szkolno-Wychowawczego w Kęble:

Akt nadania imienia.

Akt założycielski Szkoły przysposabiającej do pracy zawodowej dla upośledzonych umysłowo w stopniu umiarkowanym i znacznym w Kęble.

Kronika Państwowego Domu Dziecka w Kęble.

${ }^{54}$ Ibidem. 


\section{Opracowania}

Broszura: Oferta edukacyjna Specjalnego Ośrodka Szkolno-Wychowawczego im. świętego Franciszka z Asyżu w Kęble.

Czerwińska E., Dzieci świętego Franciszka, „Kurier Lubelski” 267 (2002), s. 4-5.

Edukacja w Powiecie puławskim 2011/2012, Powiat puławski, Puławy 2011.

Historia, zabytki, turystyka, informator, mapa gminy. Wawolnica. Przewodnik, opracowanie: Biuro Public Relations.

Jędrych S., Ludwika Leokadia Tomczuk, w: Biografie nauczycieli zastużonych dla oświaty i środowiska regionu puławskiego, tom trzeci, red. S. Pać i in., Wydawca: Towarzystwo Muzeum Oświatowego w Puławach, Puławy 2007, s. 79-81.

Jędrych S., Mikołaj Tomczuk, w: Biografie nauczycieli zastużonych dla oświaty i środowiska regionu puławskiego, tom trzeci, red. S. Pać i in., Wydawca: Towarzystwo Muzeum Oświatowego w Puławach, Puławy 2007, s. 82-83.

Kuś H., Wąwolnica i okolice, Wydawnictwo Językowe Apart, 2005.

Pluta M., Rekreacja - jeden z celów hipoterapii?, w: Koń w turystyce i rekreacji, red. K. Chmiel, Państwowa Szkoła Wyższa im. Papieża Jana Pawła II w Białej Podlaskiej, Instytut Turystyki i Rekreacji, Biała Podlaska 2009, s. 63-72.

Rostworowski S., Rostworowscy w Kęble, „Gazeta Wąwolnicka” 7 (2004).

Stelmach I., Mate ojczyzny - Kębło, „Widnokrąg” 2 (2006), s. 15-16.

Wąwolnica, seria: Pod herbami, Wydawnictwo MAKI, Lublin.

\section{Strony internetowe}

http://zsosw.net.pulawy.pl/keblo/o_osrodku.html [9.04.2015].

http://panel.lfoz.lublin.pl/index/show/id/1097/nazwa/keblo-dwor\#Files [5.02.2012].

http://www.sanktuarium-wawolnica.pl/czytelnia/Rostworowski\%20dziedzic\%20Kebla\%20pdf.pdf

[11.04.2015]

http://www.sanktuarium-wawolnica.pl/index.php?m=objawienia [10.04.2015].

http://zsosw.net.pulawy.pl/keblo/o_osrodku.html [9.04.2015]. 
